\title{
The Establishment of Polarity by Hippocampal Neurons in Culture
}

\author{
Carlos G. Dotti, Christopher A. Sullivan, and Gary A. Banker \\ Department of Anatomy, Cell Biology and Neurobiology, Albany Medical College, Albany, New York 12208
}

By the end of the first week in culture, hippocampal neurons have established a single axon and several dendrites. These 2 classes of processes differ in their morphology, in their molecular composition, and in their synaptic polarity (Bartlett and Banker, 1984a, b; Caceres et al., 1984). We examined the events during the first week in culture that lead to the establishment of this characteristic form. Hippocampal cells were obtained from $18 \mathrm{~d}$ fetal rats, plated onto polylysinetreated coverslips, and maintained in a serum-free medium. The development of individual cells was followed by sequential photography at daily intervals until both axons and dendrites had been established; identification of the processes was contirmed by immunostaining for MAP2, a dendritic marker. Time-lapse video recording was used to follow the early stages of process formation.

Hippocampal neurons acquired their characteristic form by a stereotyped sequence of developmental events. The cells first established several, apparently identical, short processes. After several hours, one of the short processes began to grow very rapidly; it became the axon. The remaining processes began to elongate a few days later and grew at a much slower rate. They became the cell's dendrites. Neurons that arose following mitosis in culture underwent this same sequence of developmental events. In a few instances, 2 processes from a cell exhibited the rapid growth typical of axons, but only one maintained this growth; the other retracted and became a dendrite. Axons branched primarily by the formation of collaterals, not by bifurcation of growth cones.

As judged by light microscopy, processes are not specified as axons or dendrites when they arise. The first manifestation of neuronal polarity is the acquisition of axonal characteristics by one of the initial processes; subsequently the remaining processes become dendrites.

Under special circumstances, it is possible to observe the growth of living axons and dendrites in situ (Speidel, 1941, 1942; Eisen et al., 1986; Purves et al., 1986), but our understanding of the dynamic properties of developing neurites derives in great part from studies of cells in tissue culture (e.g., Bray, 1970, 1973; Yamada et al., 1970). Such work has elucidated much about

\footnotetext{
Received July 9, 1987; revised Sept. 11, 1987; accepted Sept. 14, 1987.

This research was supported by National Institutes of Health Grant NS 17112. C.G.D. was supported in part by a Fogarty International Fellowship (1F05 TWO 3703). C.A.S. was supported by a National Institutes of Health Short Term Training Grant (5-P35 HL 07506). We wish to thank Colleen Fitzgerald for her excellent technical assistance, Deirdre Ouderkirk for help with photography and preparation of the manuscript, and Jeff Deitch and Kimberly Goslin for their comments on the manuscript.

Correspondence should be addressed to $G$. Banker at the above address. Copyright (C) 1988 Society for Neuroscience $0270-6474 / 88 / 041454-15 \$ 02.00 / 0$
}

the behavior of growth cones and the mechanics of fiber elongation (e.g., Landis, 1983; Bray and Chapman, 1985; Bamburg et al., 1986), as well as about the modulation of these processes by the environment (Letourneau, 1975a, b; Gunderson and Barrett, 1980; Patel and Poo, 1984).

The great majority of this work has been undertaken with cultures of neurons obtained from the PNS. Although the cell biological mechanisms underlying process outgrowth are likely shared by most classes of nerve cells, important features of the development of central neurons are not exhibited by PNS cells. For example, at the stage typically employed for such studies, all of the processes of peripheral neurons appear similar to one another. By contrast, most CNS cells elaborate 2, quite distinct, classes of processes, axons, and dendrites, which differ profoundly in shape and function. How is it that these more complex cells acquire their distinctive axonal and dendritic architecture?

To address this question, we have studied in cell culture the development of CNS neurons derived from the embryonic hippocampus. Previous work has shown that, by the end of the first week in vitro, hippocampal cells have developed well-differentiated axonal and dendritic domains (for review, see Banker and Waxman, 1987). The 2 types of processes differ from each other in morphology (Bartlett and Banker, 1984a, b), in capacity for protein synthesis (Davis et al., 1987), in certain of the molecular constituents of their cytoskeletons (Caceres et al., 1984, 1986; Shaw et al., 1985) and of their plasma membranes (Banker and Mazurkiewicz, 1982), and in synaptic polarity (Bartlett and Banker, 1984b) - just as do thcir countcrparts in situ. Dendrites are relatively short, tapering processes that contain polyribosomes and synthesize proteins. MAP2 is associated with their cytoskeletons, and bungarotoxin-binding sites are expressed on their surfaces. Axons-long, thin, and relatively uniform in diameter-lack polyribosomes, MAP2, and bungarotoxin receptors, but contain synaptic vesicle-associated proteins (Lindsley et al., 1987) and in some cases a distinctive neurofilament subunit (Shaw et al., 1985). Dendrites in hippocampal cultures are exclusively postsynaptic, axons are presynaptic.

The present paper is concerned with early events in the development of axons and dendrites in culture. By what sequence of morphological events are hippocampal neurons transformed from apolar neuroblasts to polarized cells with distinct axonal and dendritic processes? We have addressed this question by following individual hippocampal cells throughout the course of their development in culture. To our knowledge these are the first observations of these events in living CNS neurons.

\section{Materials and Methods}

Cell culture. To permit long-term observation of living cells under acceptable optical conditions, special culture dishes were used. These were 
prepared from plastic petri dishes with tight-fitting lids (Falcon 1006) by drilling a $16 \mathrm{~mm}$ hole in the bottom and attaching an acid-cleaned glass coverslip ( $22 \mathrm{~mm}$ in diameter) to the outer surface of the dish with a mixture of paraffin and Vascline (3:1). A glass ring, $18 \mathrm{~mm}$ in diameter and $5 \mathrm{~mm}$ deep (Thomas Scientific), was sealed to the inside of the dish with silicone grease, forming a $1 \mathrm{ml}$ well above the coverslip. The inner surface of the coverslip was treated with polylysine, rinsed with water, and the well was filled with medium.

Methods for preparing the hippocampal cell cultures have been previously described (Banker and Cowan, 1977; Bartlett and Banker, 1984a). Briefly, hippocampi were dissected from the brains of $18 \mathrm{~d}$ rat fetuses, treated with $0.25 \%$ trypsin for $15 \mathrm{~min}$ at $37^{\circ} \mathrm{C}$, washed in $\mathrm{Ca}-\mathrm{Mg}$-free Hanks' balanced salt solution, and dissociated by repeated passage through a constricted Pasteur pipette. Between 2000 and 6000 cells were added to the special culture dishes in Minimun Essential Medium (MEM) containing $10 \%$ horse serum. After $3-4 \mathrm{hr}$ at $37^{\circ} \mathrm{C}$, when the cells had attached to the substrate, the media was replaced with MEM, supplemented with $10 \mathrm{mM}$ HEPES (pH 7.3), pyruvate $(0.01 \mathrm{mg} / \mathrm{ml}$ ), and the N2 mixture of Bottenstein and Sato (1979). To enhance neuronal survival (Banker, 1980), a coverslip containing a confluent monolayer of astroglial cells (Booher and Sensenbrenner, 1972) was placed on the top of the glass ring, with the glia facing the neurons.

Observations of living neurons. Cultures were observed using a Zeiss IM35 inverted microscope. The temperature was maintained at approximately $37^{\circ} \mathrm{C}$ using an air curtain incubator (Sage Instruments).

In one series of experiments, the development of individual cells was followed at daily intervals. After $24 \mathrm{hr}$ in vitro, cells were selected and circled with a diamond object marker so that they could be relocated. They were then photographed and the cultures were returned to a $\mathrm{CO}_{2}$ incubator. Cells were rephotographed at intervals of about $24 \mathrm{hr}$ for 1 week.

In a sccond series of experiments, time-lapse recordings were made using a Dage-MTI camera (Model 67M) equipped with a Newvicon tube and a Panasonic video recorder (Model AG-6050). Recordings were made using phase-contrast optics with 16 or $25 \times$ objectives with illumination from a $100 \mathrm{~W}$ tungsten source passed through a green filter. The recordings were begun about $4 \mathrm{hr}$ after plating and maintained continuously for $30-40 \mathrm{hr}$.

Immunocytochemistry. In some instances, cells that had been followed photographically or by time-lapse recording were stained to localize MAP2, a neuron-specific microtubule-associated protein that is restricted to the somatodendritic domain (Caceres et al., 1986). Cells were marked by inscribing a circle on the bottom of the glass coverslip with a diamond object marker. The cells were then fixed and, after the coverslip was gently pried from the dish, were processed for immunocytochcmistry using the peroxidase-antiperoxidase procedure, as previously described (Caceres et al., 1984, 1986).

Measurement of growth rate. The rate of growth of neuronal processes was measured from drawings of the cells, using a digitizing tablet (GTCO) and appropriate software (SigmaScan, Jandel Scientific). For cells that had been followed by photography, prints were prepared at a consistent magnification and tracings made from the prints. By superimposing tracings from successive photographs, it was possible to identify individual processes with certainty and to follow their growth and branching. For cells that had been followed by video recording, tracings were made directly from the video monitor at intervals of $1 \mathrm{hr}$.

\section{Results}

Origin of axons and dendrites

After growth for $7 \mathrm{~d}$ in culture, individual hippocampal neurons reproducibly display a characteristic shape: they have a single, long axon of relatively uniform diameter, and several shorter, tapering dendrites (Bartlett and Banker, 1984a). The objective of the first set of experiments in the present study was to determine the sequence of developmental events during the first week in culture that leads to the establishment of this characteristic morphology.

Individual cells in low-density cultures were selected after 1 $d$ in culture and photographed. The same cells were subsequently relocated and photographed at daily intervals until definitive axons and dendrites could be identified. By analyzing each sequence of photographs retrospectively, it was possible to deter- mine which of the early processes gave rise to the definitive axons and which to the dendrites. In all, 17 cells were studied in this manner; of these, 11 were suitable for detailed measurements of process growth.

All of the cells observed underwent the same basic series of developmental changes. The cell illustrated in Figure 1 is, in most regards, typical. After 1 or $2 \mathrm{~d}$ in culture, as first described by Banker and Cowan (1977), most cells are asymmetric in shape: they have a single, long "major" process and several "minor" processes of much shorter length. At this stage, the major process averaged $80-100 \mu \mathrm{m}$ in length and the minor processes $10-15 \mu \mathrm{m}$. The mean number of minor processes, measured at $24 \mathrm{hr}$, was $4.9(n=17)$. The time of appearance of this morphology varied somewhat among different cells, even within the same culture. The majority of cells had a clcarly distinguishable major process after $24 \mathrm{hr}$ in culture, but some, such as the cell illustrated in Figure $1 A$, had only minor processes; by $48 \mathrm{hr}$ nearly all cells had one major process and several minor processes (Fig. $1 B$ ).

How are the major and minor processes related to the axons and dendrites that can be definitively identified at later stages of development? Figure 1, $C-E$, which illustrates the development of this same cell after 3,5 , and $7 \mathrm{~d}$ in culture, shows that with continued growth the major process acquired all the morphological features characteristic of axons in culture, and that the minor processes acquired dendritic characteristics, as defined in previous studies (Bartlett and Banker, 1984a). These features were recognizable by $5 \mathrm{~d}$, and obvious by $7 \mathrm{~d}$. Following its emergence on day 2 , the axon continued to elongate relatively rapidly, reaching $300 \mu \mathrm{m}$ from the soma by day 7 . At least 4 branches could be identified (A1-A4), emerging from the main axon between days 2 and 6 . One of these branches (A1) retracted, while the others continued to elongate, some reaching distances farther from the soma than the tip of the parent axon. Several of the axonal branches of this cell (A3, A4, A3-1) arose not by bifurcation of the axonal growth cone, but as collaterals that emerged from the main process 2 or $3 \mathrm{~d}$ after the passage of the axonal growth cone. The mode of origin of the other branches (A1 and A2) could not be determined from the data available, since growth of the parent axon and the emergence of these branches both occurred in the interval between the photographs taken on days 1 and 2 (Fig. $1, A, B$ ). In general, most axonal branches in these cultures arose by collateralization. From observations of 19 cells in which branching occurred (including cells followed by video recording; see below), unambiguous instances of collateral branching were seen in 16 cases.

Between day 2 and day 4, when the axon of the cell illustrated in Figure 1 was growing rapidly and branching, there was relatively little change in the length or appearance of the minor processes. These processes began to elongate on day 5, reaching lengths of up to $75 \mu \mathrm{m}$ on day 7 . By this stage they exhibited the taper characteristic of dendrites; this was most obvious in the longer processes, such as D1 (see also Fig. 3).

The rates of clongation of the major process and its branches, and of several of the minor processes of the cell illustrated in Figure 1, are quantified in Figure 2. From day 2, when the axon could first be distinguished, it grew at an average rate of about $60 \mu \mathrm{m} / \mathrm{d}$, at least 5 times faster than the rate of growth of the most rapidly elongating dendrite. All of the branches that emerged from the axon also grew at about this rate. None of the dendrites exhibited significant net elongation during the first $4 \mathrm{~d}$ in culture. Subsequently, they elongated at rates of about $12 \mu \mathrm{m} / \mathrm{d}$. On the 

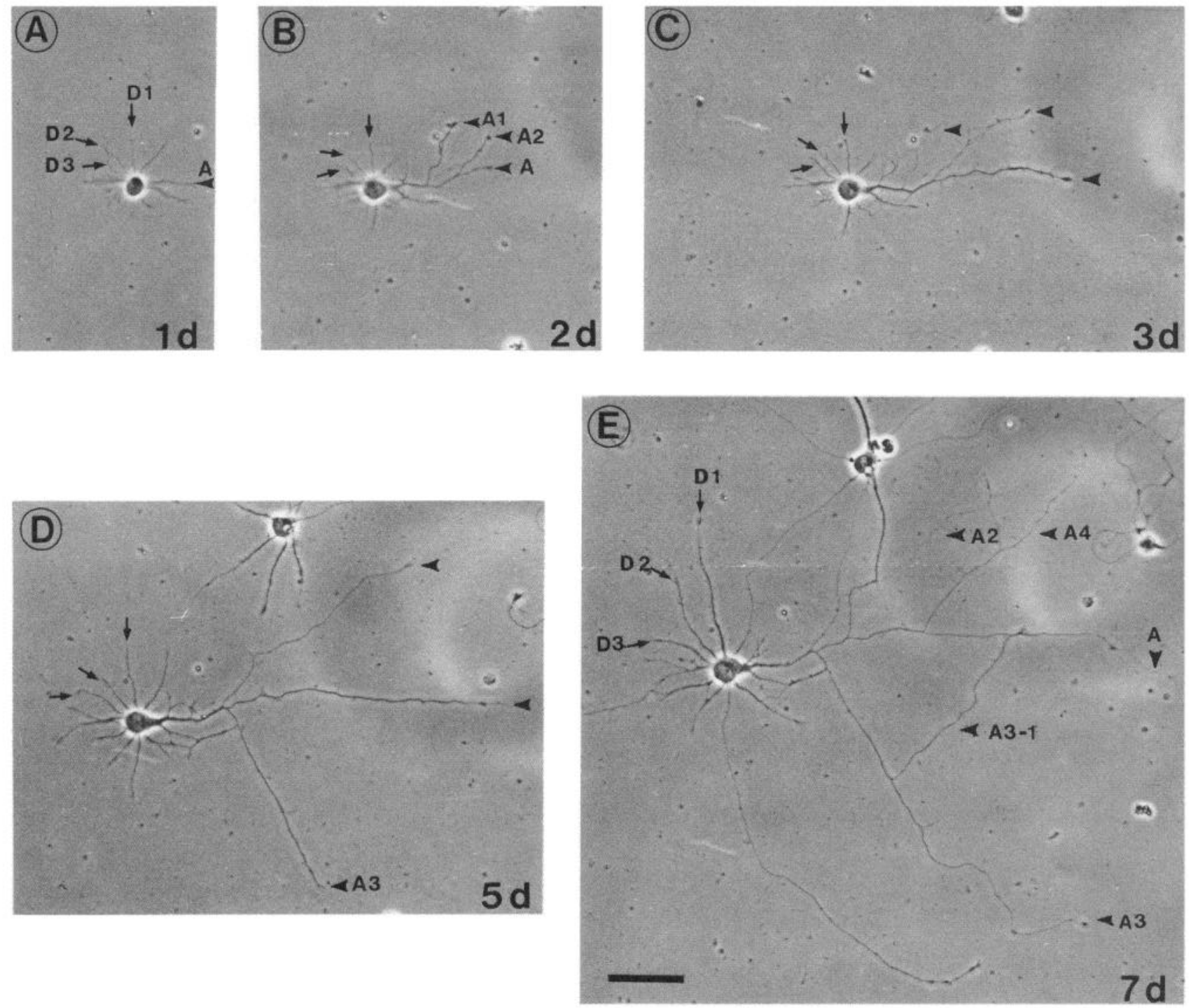

Figure 1. Series of phase-contrast photomicrographs illustrating the development of axonal and dendritic arbors by a single hippocampal neuron. The growth rate of several of the processes $(D I-D 3$ and $A)$ is quantified in Figure $2 . A$. After $1 \mathrm{~d}$ in culture, the cell had developed several short processes which resembled one another in morphological appearance. $B$, On the second day in culture, one of the processes $(A)$ elongated considerably more than the others, giving the cell the appearance typical of young hippocampal neurons in culture, with a single, long major process and several minor processes. Two branches emerged from the major process ( $A 1$ and $A 2)$. $C$, After $3 \mathrm{~d}$ in culture, the major process had elongated still further, while the minor processes remained essentially stationary. One of the branches of the major process $(A 2)$ also elongated considerably; the other (AI) did not. D, After $5 \mathrm{~d}$ in culture, the identity of the cells' processes had become clear: the major process had become the axon, the minor processes dendrites. The axon $(A)$ and one of its collaterals $(A 2)$ had elongated still further; another collateral $(A 1)$ retracted, and a new collateral (A3) formed. The dendrites also had begun to elongate. $E$. After $7 \mathrm{~d}$ in culture, the axon and its branches had elongated still more, and 2 new branches had formed $(A 3-1, A 4)$. The dendrites had also elongated significantly, some at a faster rate than others. Axons from neighboring cells contacted and grew along some of the cell's processes so that they could not be traced and measured unambiguously. All photomicrographs are at the same magnification. Scale bar, $20 \mu \mathrm{m}$.

basis of the rate of growth, as well as of morphological appearance, every process from this cell expressed characteristics of either an axon or a dendrite; no processes grew at intermediate rates.

Drawings illustrating the development of a second cell are shown in Figure $3 A$. On day 1 , this cell had only minor processes (not shown); by day 2, a single axon that already exhibited extensive branching had emerged. By day 4, the axon had elongated further, and additional branches that arose by collateralization could be seen (Fig. $3 A$, asterisks). By this stage, one of the minor processes (dendrite 2) had begun to elongate and to take on the appearance of a dendrite. By day 7 , the axon had become much more elaborately branched and several dendritic processes could be distinguished. To verify that the processes derived from the major and minor processes of this cell were indeed axon and dendrites, the cell was fixed on day 7 and immunostained to demonstrate the localization of MAP2, a dendritic marker. As expected, on the basis of morphology and growth rate, the process identified as the axon showed little or no MAP2 immunoreactivity. Six of the 7 minor processes present on day 2 persisted and became dendrites, as judged by their morphology and MAP2 staining.

As is common for hippocampal neurons in culture, the axon of this cell arose as a branch from a short process that had 
dendritic characteristics, including MAP2 immunoreactivity. The other branch arising from this point (arrowheads, Fig. 3) had dendritic features. This organization was already apparent at day 2 (Fig. $3 \mathrm{~A}$ ); from this stage on, one of the branches that arose at this point grew rapidly and branched like an axon; the other grew much more slowly and took on dendritic characteristics.

The average rate of process elongation between 1 and $7 \mathrm{~d}$ in culture, based on an analysis of 11 cells, is summarized in Figure 4, which illustrates the length between the cell body and the distal tip of the axon and of the longest dendrite. On average, the axon had reached a distance of $40 \mu \mathrm{m}$ from the soma after $1 \mathrm{~d}$ in culture and then elongated by about $70 \mu \mathrm{m} / \mathrm{d}$ for the next few days. Later its elongation slowed somewhat. Significant dendritic elongation began between days 3 and 5; the most rapidly growing dendrites elongated at an average rate of about $12 \mu \mathrm{m}$ / d between day 5 and day 7 .

\section{Early events in the establishment of polarity}

The preceding observations show that hippocampal neurons become polarized within the first $2 \mathrm{~d}$ in culture. At that time they typically have a single long axon and several shorter, minor processes that will subsequently elongate to become the cell's dendrites. What is the sequence of developmental events occurring during the first $2 \mathrm{~d}$ in culture that leads to the acquisition of this shape? To address this question, we made continuous time-lapse video recordings of individual cells, beginning a few hours after plating and continuing for 18-44 hr, until the cells' polarity was definitively established. Our data include complete recordings of 9 cells, as well as recordings of many other cells that illustrate portions of the developmental sequence. On this basis it was possible to distinguish 3 stages of development leading to the establishment of polarity: (1) formation of lamellipodia, (2) outgrowth of minor processes, and (3) transformation of one of the minor processes into the axon. We will first describe the typical morphology of cells at each of these stages of development, and then trace the history of individual cells during the establishment of polarity.

Figure 5 shows a single neuron that was photographed at each of these stages of development. When introduced into culture, cells lack processes and are essentially spherical; attachment occurs during the first hour or 2 (Banker and Cowan, 1977). The first change in the cell's appearance was marked by the development of lamellipodia around the circumference of the cell body (Fig. 5A). These flat, veil-like structures were constantly in motion, extending, undulating, and retracting, so that their shape changed from minute to minute. Sometimes the lamellipodia extended around the entire circumference of the cell; at other times they coalesced into a few discrete zones around the periphery.

The second phase of development was marked by the loss of lamellipodia and the extension of short neurites, which we have designated minor processes. These were quite different from lamellipodia in their morphology and behavior. Minor processes appeared to be cylindrical in cross section, not flattened, although they frequently had expanded, flattened, growth cones at their tips. Once established, minor processes were quite stable; they might increase or decrease in length, but they typically persisted for days. Regions of minor processes exhibiting motility were confined to lateral microspikes and, during periods of extension, to growth cones. Immunofluorescence experiments showed that minor processes contained arrays of microtubules

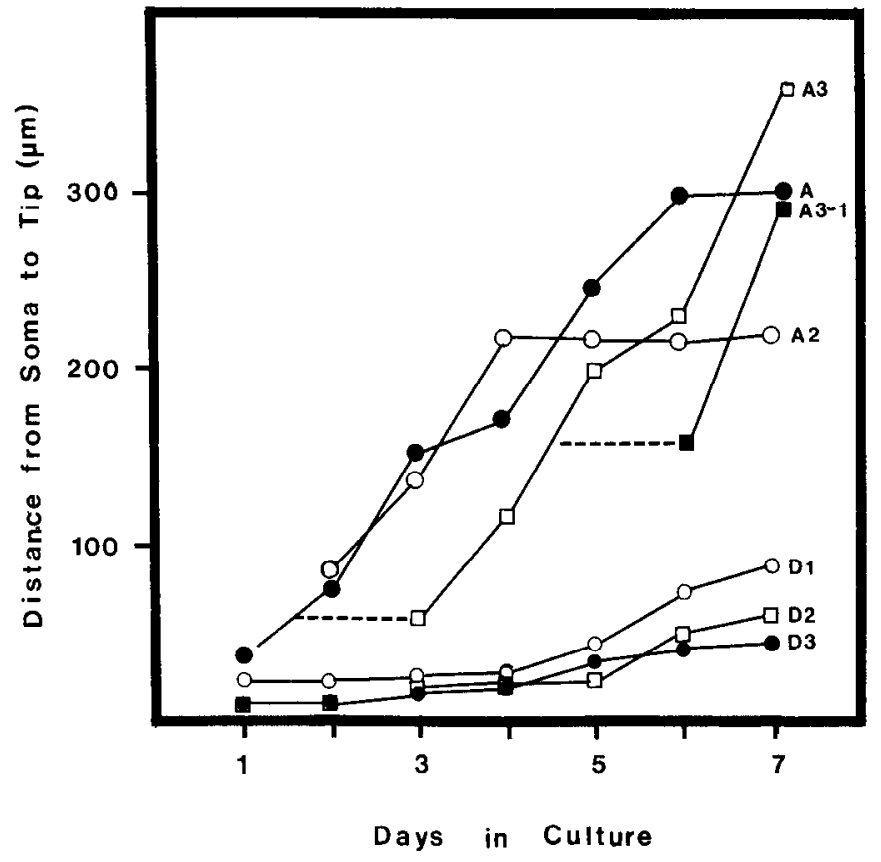

Figure 2. The rate of advance of the axon $(A), 3$ axonal branches $(A 2$, $A 3, A 3-1)$, and 3 dendrites $(D 1-3)$ from the cell shown in Figure 1. The axon and its branches advanced at approximately 5-10 times the rate of the dendrites. Two of the axonal branches, A3 and A3-1, arose by collateral branching (on days 3 and 6, respectively) from points along the parent processes that had formed $1-2 \mathrm{~d}$ previously (dashed lines). Lengths were measured from the cell body along the neurites to their tips.

oriented parallel to their long axis; lamellipodia contained a predominance of actin filaments, with only occasional, unoriented microtubules (unpublished observations). Thus, although the minor processes were quite short-on average about $10 \mu \mathrm{m}$ in length - they exhibited definitive features of neurites, quite distinct from those of lamellipodia.

At early stages, processes that were transitional in appearance between lamellipodia and minor processes were observed. These were typically expanded and flattened proximally, but took on a neuritic appearance more distally (arrows, Fig. $5 B$ ). With time the lamellipodial features were lost entirely (compare Fig. 5, $B$ and $C$ ).

The establishment of polarity in hippocampal neurons was marked by the transformation of one of the minor processes into the axon (Fig. 5C). This did not involve an obvious change in its appearance, but simply a marked increase in its rate of elongation. The newly formed axon had many microspikes along its length and a prominent growth cone at its tip. All of these structures were highly motile-forming, moving, then disappearing.

Figure 6 illustrates the development of 4 cells that were recorded continuously, beginning $4 \mathrm{hr}$ after plating and continuing for $42 \mathrm{hr}$. Each of thesc cells went through the sequence of developmental changes described above, but the time when these events occurred varied considerably from cell to cell. We will first describe the development of cells 1 and 2, since they exemplify the typical sequence of events observed during the establishment of polarity. We will then consider cells 3 and 4, which illustrate variations from the typical pattern.

When the recording was begun ( $4 \mathrm{hr}$ after plating), cell $1 \mathrm{had}$ just begun to extend minor processes (Fig. $6 \mathrm{~A}$ ); these reached 
(A)
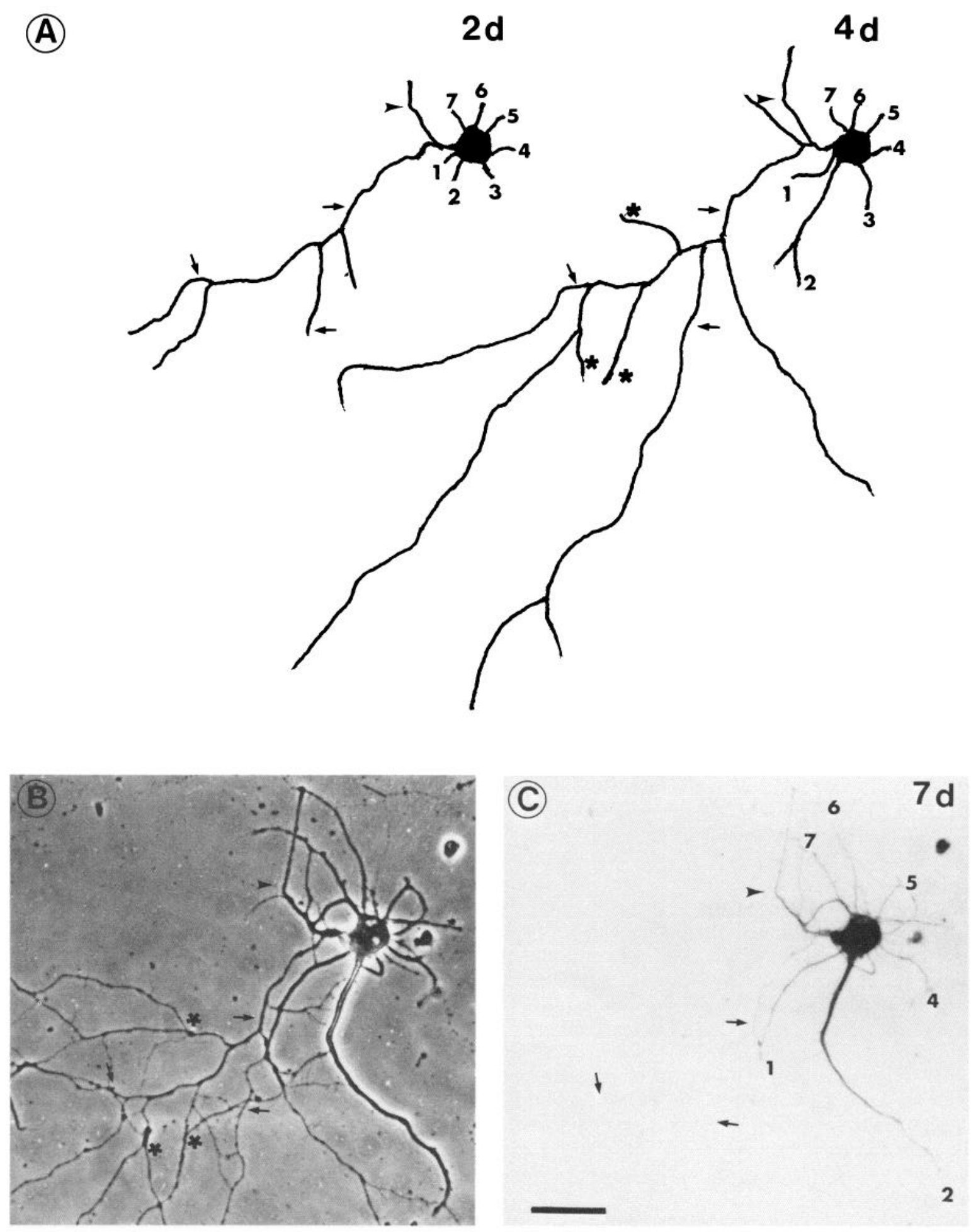

Figure 3. Another example of axonal and dendritic outgrowth by a hippocampal neuron in culture. $A$, Drawings taken from photomicrographs after 2 and $4 \mathrm{~d}$ in culture illustrate the development of the axon (arrows) and the 7 minor processes $(1-7)$. Several collateral branches arose from the axon between days 2 and 4 (asterisks). On day 7 the cell was fixed and immunostained to localize MAP2. The phase-contrast photomicrograph $(B)$ illustrates the cell's dendrites and the proximal portion of its extensive axonal arbor. By bright-field microscopy $(C)$, there is little MAP2 staining of the axon and its many branches. Six of the 7 minor processes that were present at day 2 have elongated and are MAP2-positive; the seventh (3) may have partially or completely retracted. The axon arises as a branch from a short process that contains MAP2. The other branch that arose at this point (arrowhead) resembles the cell's other dendrites in length, tapering appearance, and content of MAP2 throughout. Note that the peroxidase reaction product also increases the density of the stained processes, as seen by phase-contrast microscopy. Scale bar, $15 \mu \mathrm{m}$. 
their characteristic length about $3 \mathrm{hr}$ later, showing little net elongation thereafter. Throughout this period, cell 2 remained in the lamellipodial stage. Beginning about $8 \mathrm{hr}$ after plating, one of the minor processes of cell 1 (arrowheads, Fig. 6C) began to extend rapidly, reaching a lenth of $60 \mu \mathrm{m}$ in $2 \mathrm{hr}$, when its growth temporarily stopped. The cell's 3 other minor processes persisted unchanged during this period, and a fourth emerged at $10 \mathrm{hr}$ after plating. After remaining stationary for $3 \mathrm{hr}$, the axon of cell 1 resumed its elongation. The continued development of this cell was marked by a series of cycles of axonal elongation and stability.

The rate of growth of the axon and of 3 of the minor processes from cell 1 are illustrated in Figure $7 A$, which records the length of each process at hourly intervals. All 4 of the processes were present $4 \mathrm{hr}$ after plating, and their rates of elongation were indistinguishable for the next $5 \mathrm{hr}$. Abruptly, one increased its rate of elongation almost 10 -fold, and within $2 \mathrm{hr}$ could be identified as the cell's axon. This was in marked contrast to the behavior of the remaining minor processes, which continued to elongate and retract at their characteristic slow rate for the next $24 \mathrm{hr}$, as the axon underwent additional cycles of intermittent elongation. The phases of axonal elongation sometimes ended with a slight retraction of the axon.

Cell 2 followed a generally similar pattern of development, although the emergence of its minor processes occurred somewhat later, between 15 and $20 \mathrm{hr}$ after plating (Fig. 6, D,E). Like cell 1 , the axon of cell 2 underwent cycles of elongation and stability (data not shown). As its growth continued, it gave rise to 3 axonal branches, one at about $26 \mathrm{hr}$ after plating, 2 others between 27 and $36 \mathrm{hr}$ after plating (Fig. 6, $G-I$ ). In each case these arose as collaterals at a position proximal to the growth cone. As each branch emerged, elongation at the tip of the original axon stopped; frequently the nongrowing portion of the axon, distal to the new branch, became thinner in diameter. The branches that developed from this cell arose, in temporal order, at 46 (a2), 76 (a1), and 83 (a3) $\mu \mathrm{m}$ along the axon; these branches developed at 26 (a1), 29 (a3), and 31 (a2) $\mathrm{hr}$ after the initial growth cone had passed the point from which these collaterals subsequently arose. At the magnification used for these recordings, it was not possible to identify any consistent characteristic that marked the site along the axon from which a future branch would emerge.

Data describing several features of axonal development for 9 cells that were analyzed in detail are summarized in Table 1. In general, each cell underwent the developmental events described in detail for cells 1 and 2, above. In every case the axon arose from one of the cell's minor processes, although the time at which the axon began its phase of rapid elongation varied from 8 to $27 \mathrm{hr}$ after plating. The maximal rate of axonal elongation (measured during the $2 \mathrm{hr}$ period that showed the greatest net elongation) averaged $20 \mu \mathrm{m} / \mathrm{hr}$, but the average rate of extension (measured over the $18 \mathrm{hr}$ period from initiation of axonal outgrowth) was only $6 \mu \mathrm{m} / \mathrm{hr}$. This difference largely reflects the cyclic nature of axonal elongation.

\section{How does the axon become determined?}

One of the most consistent and striking features of these observations concerns the origin of the axon: it arises from one of the several minor processes characteristic of the second stage of cell development. So far as we have been able to judge, nothing marks this minor process as distinctive until its rapid elongation actually begins. It is not consistently the earliest or the latest of

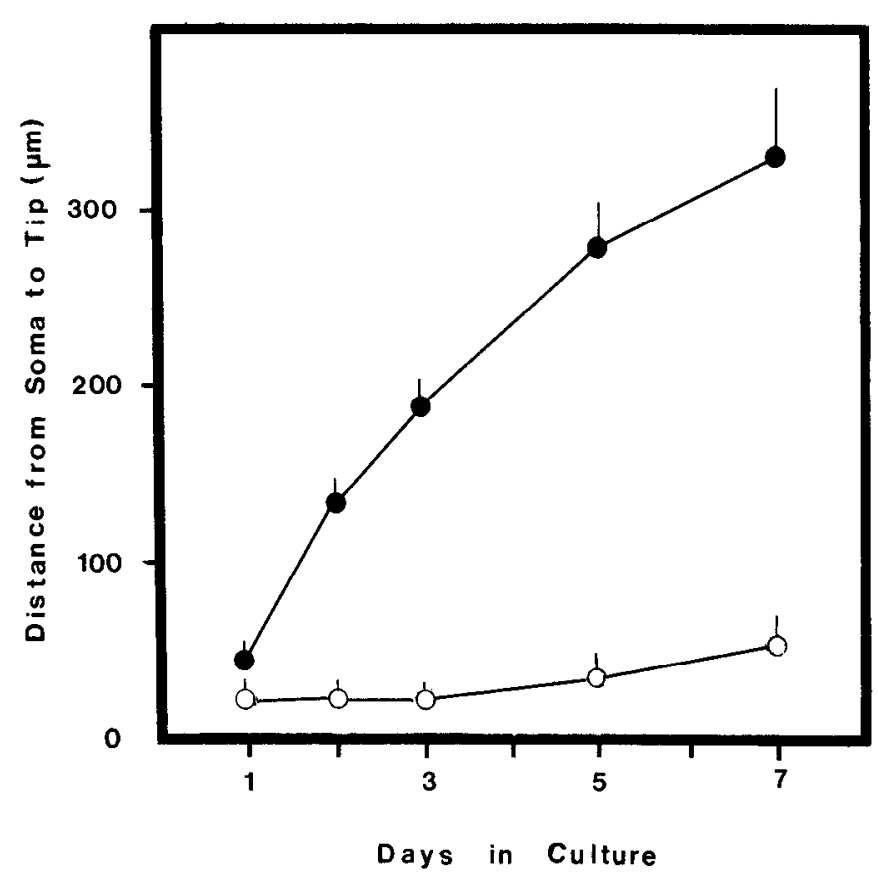

Figure 4. Average rate of elongation of axons and dendrites from hippocampal neurons during the first week in vitro. Data are based on measurements of the longest branch of the axon (filled circles) and of the longest dendrite (open circles) from 11 cells (mean and SEM) that were photographed at daily intervals. The pronounced difference in the rate of elongation of axons and dendrites is evident. Note that significant dendritic elongation does not begin until after day 3 .

the minor processes to develop, its initial rate of elongation is no different from that of the other minor processes, the behavior of its growth cone is not unique. These observations raise the possibility that the axon is not specified when it first arises from the cell. Rather, more than one of the minor processes might be capable of becoming axons.

The stages of axonal development exhibited by cells 3 and 4 of Figure 6 offer further support for this possibility. In the case of cell 3 , one of the minor processes assumed an axonal character about $24 \mathrm{hr}$ after plating (compare Fig. 6, F, G). At about 26

\begin{tabular}{|c|c|c|c|c|}
\hline \multirow{3}{*}{$\begin{array}{l}\text { Cell } \\
\text { number } \\
1\end{array}$} & \multirow{2}{*}{$\begin{array}{l}\text { Formation } \\
\text { of minor } \\
\text { processes } \\
\text { (after platin }\end{array}$} & \multirow{2}{*}{$\begin{array}{l}\text { Initiation } \\
\text { of axons } \\
\mathrm{g}, \mathrm{hr} \text { ) }\end{array}$} & \multicolumn{2}{|c|}{$\begin{array}{l}\text { Axonal growth rate } \\
(\mu \mathrm{m} / \mathrm{hr})\end{array}$} \\
\hline & & & Average $^{\alpha}$ & $\begin{array}{l}\text { Maxi- } \\
\text { mum }^{\prime \prime}\end{array}$ \\
\hline & 4 & 8 & 5.0 & 17 \\
\hline 2 & 4 & 16 & 4.7 & 11 \\
\hline 3 & 6 & 9 & 8.3 & 34 \\
\hline 4 & 6 & 12 & 6.5 & 22 \\
\hline 5 & 12 & 23 & 7.1 & 17 \\
\hline 6 & 17 & 22 & 8.5 & 22 \\
\hline 7 & 21 & 24 & 6.9 & 30 \\
\hline 8 & 24 & 28 & 3.8 & 12 \\
\hline 9 & 24 & 30 & 6.3 & 18 \\
\hline Mean & 13 & 19 & 6.3 & 20.3 \\
\hline
\end{tabular}

${ }^{a}$ Based on the $18 \mathrm{hr}$ period after the beginning of stage 3 .

"Based on the $2 \mathrm{hr}$ interval of most rapid growth. 
Figure 5. Phase-contrast photomicrographs illustrating the 3 stages characteristic of the early development of hippocampal neurons in culture. $A$, In the first phase, the cell body is surrounded by flattened lamellipodia. $B$, In the second phase, the lamellipodia become transformed into definitive processes. These minor processes frequently are tipped with growth cones. During this transition, the processes are often flattened along their margins (arrows). $C$, The third phase of development is marked by the transformation of one of the minor processes into the axon (arrows). The axon has a prominent growth cone as it elongates and frequent filopodia along its length. In the interval between micrographs $B$ and $C$, the minor processes became more cylindrical in cross section, but showed no net elongation. One new minor process also developed in this interval (arrowheads in $C$ ). The cell illustrated was photographed at $4 \mathrm{hr}(A), 14 \mathrm{hr}(B)$, and 20 $\mathrm{hr}(C)$ after plating. Scale bar, $10 \mu \mathrm{m}$.
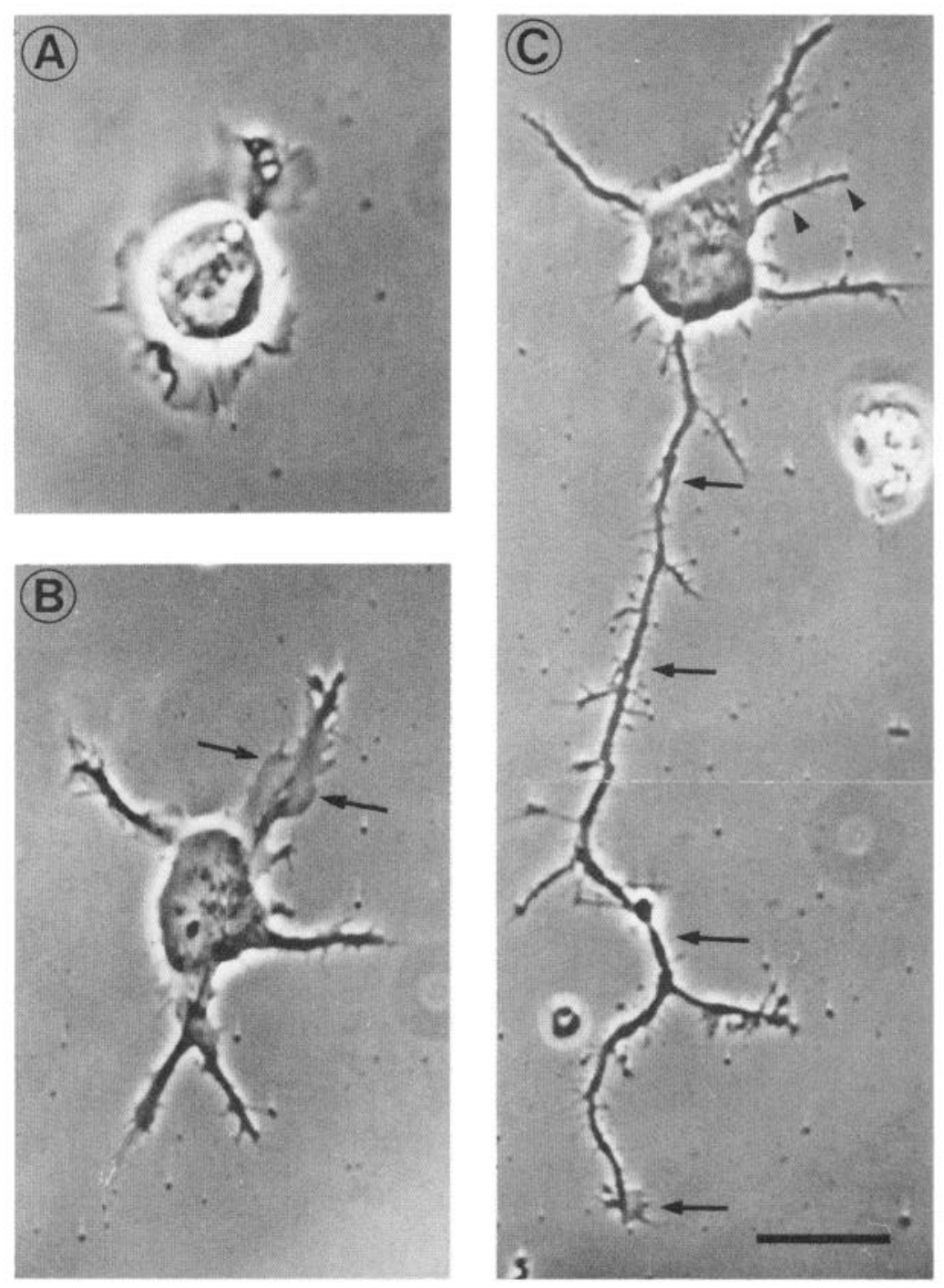

$\mathrm{hr}$ after plating, this process ceased elongating and one of the other minor processes (Fig. $6 \mathrm{H}$, b) began to grow at a rate characteristic of axons. At $29 \mathrm{hr}$ this process stopped elongating and process a again began to grow rapidly, ultimately becoming the cell's definitive axon. Process b retracted and came to resemble the cell's remaining minor processes (Fig. $6, I, J$ ). These observations are quantified in Figure $7 B$. During their periods of rapid elongation, both processes $\mathrm{a}$ and $\mathrm{b}$ grew at identical rates (about $25 \mu \mathrm{m} / \mathrm{hr}$ ), well within the range of rates characteristic of definitive axons. Each process stopped growing when rapid growth of the other began; during these nongrowing phases, both processes a and b actually retracted for $25 \mu \mathrm{m}$ or more. When process a had clearly become the definitive axon, process $b$ retracted to the length of the cell's remaining minor processes, and its subsequent pattern of growth became indistinguishable from that of the other minor processes.

In the case of cell 4 , one of the minor processes first acquired axonal characteristics after $27 \mathrm{hr}$ in culture. Within $2 \mathrm{hr}$, it extended $46 \mu \mathrm{m}$ and then stopped. A new process developed from near the base of the first, grew rapidly, and became the cell's definitive axon. As this happened, the first axon slowly retracted and became indistinguishable from the other minor processes. These results show that more than one of the minor processes that arise from a cell has the capacity to elongate at a rate characteristic of definitive axons. We have not observed an instance in which 2 processes elongated at axonal rates simultaneously.

\section{Cell division and the establishment of polarity}

At $18 \mathrm{~d}$ of gestation, when cells are taken for culture, the great majority of hippocampal neurons have undergone their final cell division, but neuronal proliferation has not ceased completely (Banker and Cowan, 1977; Schlessinger et al., 1978). Thus one might expect an occasional cell to divide in culture and give rise to neurons, although, to our knowledge, no one has previously reported observing such a mitotic event. Such cells would be of particular interest, since their polarization in culture could not simply represent a reiteration of prior events that occurred in situ.

We were fortunate enough to obtain records of one such instance, shown in Figure 8 . This cell underwent division about $10 \mathrm{hr}$ after plating (Fig. 8, $A, B$ ). Following mitosis, both daughter cells underwent the same series of morphological changes leading to the appearance of the axon that have already been described for postmitotic hippocampal neurons. They developed lamellipodia and established minor processes; then one of 
the minor processes elongated at a much more rapid rate and acquired axonal characteristics. By $20 \mathrm{hr}$ after mitosis (Fig. 8C), both cells had the typical appearance of polarized neurons, with a single axon and several shorter, minor processes.

To ensure that these 2 cells were indeed neurons and were capable of establishing well-differentiated axonal and dendritic domains, they were allowed to develop for 6 more days. They were then fixed and stained to localize MAP2. By this time the axons of both cells had become much longer and had developed several branches, and the dendrites had grown and acquired their characteristic shapes (Fig. 8D). Both cells expressed MAP2, a specific marker for neurons, and both compartmentalized it to the somatodendritic domain (Fig. $8 E$ ). In all of these respects, the cells were quite comparable to the other neurons that do not divide in culture (such as cell on the left in Fig. 8). Since, in this instance, all of the events between mitosis and axon formation occurred in culture under direct observation, and no contacts were made with other cells, specific cell interactions during this time cannot be essential for the establishment of polarity.

\section{Discussion}

This paper presents observations of living neurons during the establishment of polarity, focusing for the first time on a class of cells that develop distinct axonal and dendritic processes. From these observations it has been possible to establish the sequence of morphological events leading from an apolar neuroblast to a fully polarized neuron. Before discussing these data and their implications for a cell biological understanding of neuronal polarization, it is important to review the evidence upon which the identification of axons and dendrites is based.

\section{Identification of axons and dendrites at early stages of development}

The interpretation of the data presented in this paper is critically dependent on accurate identification of the immature processes of hippocampal neurons as precursors of either axons or dendrites. Our approach is based on sequential observation of individual cells, beginning from a very early stage, when the nature of the processes is far from obvious, and continuing for a week or more, until processes can be identified with certainty. In the present work the identification of axons and dendrites at the end of 1 week in culture was based on their characteristic differences in light-microscopic morphology and on the differential distribution of MAP2 immunoreactivity. Previous work has shown that identification of axons and dendrites on the basis of thesc properties correlates with distinctions based on electron microscopy, on the differential distribution of binding sites for alpha-bungarotoxin, and on the selective transport of newly synthesized RNA (summarized in Banker and Waxman, 1988).

After 1-2 d in culture, the great majority of hippocampal neurons have a single, long process and several shorter processes (Banker and Cowan, 1977; Matus et al., 1986). At this early stage, the processes do not resemble either mature axons or dendrites in shape, and MAP2 is uniformly distributed throughout the cell (Caceres et al., 1986). By tracing the development of individual cells, we have shown that, in every case, the longer process represents the axon; the dendrites will arise from the shorter processes. Previous attempts to infer the sequence of development of hippocampal neurons, based solely on the observation of fixed cells, have not arrived at a consistent picture. For example, Matus et al. (1986) suggested that the long process observed after 1 or $2 \mathrm{~d}$ in culture is the apical dendrite and the shorter processes the basilar dendrites, no axon being present at this stage (see also Rothman and Cowan, 1981). Some of our own interpretations of cells at a somewhat later stage of development (Banker and Cowan, 1979), which were based solely on morphology, are also probably incorrect in light of the present study and other recent work (Bartlett and Banker, 1984a; Caceres et al., 1986). Some of the processes we initially described as apical dendrites more probably represent axons (e.g., Banker and Cowan, 1979, Figs. 6a and 11e). Such errors show the importance of following individual living cells through the course of their development.

\section{Morphological stages in the establishment of axonal and dendritic domains}

The development of hippocampal neurons in culture can be divided into 5 stages, as shown schematically in Figure 9. The events of stages 1-4, which lead to the establishment of distinct axonal and dendritic domains, are the subject of the present paper; the subsequent maturation of axonal and dendritic arbors (stage 5), which continues for some weeks, is discussed elsewhere (Banker and Waxman, 1987). The distinction between stages 4 and 5, although somewhat artificial, is nonetheless important. It does not represent an abrupt, qualitative change in cell organization, but rather a change in the control of development. Cell interactions play an important role in modulating the maturation of hippocampal neurons. In contrast, the events of stages 1-4 appear to be part of an endogenously determined program of neuronal development.

Stage 1: formation of lamellipodia. Shortly after the cells attach to the substrate, motile lamellipodia develop around the periphery of the cell. In their appearance and activity, they resemble the regions of ruffling membrane associated with some classes of migrating cells in situ (Trinkhaus, 1973) and widely observed among both neuronal and non-neuronal cells in culture (Harris, 1973; Revel et al., 1974; Wessells et al., 1978). The significance of lamellipodia in neuronal development is unclear. Because comparable structures have not been observed during neuronal development in situ, their appearance in culture may reflect the cell's adaptation to growth on an artificial, 2-dimensional substrate. Nevertheless, in culture the formation of neurites appears to be associated with changes in lamellipodia. The lamellipodia, which initially surround most of the circumference of the cell, break up into discrete, motile patches at intervals along the cell periphery (see also Collins, 1978; Wessells et al., 1978). Neurites appear to arise preferentially at these sites, the lamellipodial patches becoming the neuritic growth cones.

Stage 2: outgrowth of the minor processes. This stage of development is characterized by the transformation of lamellipodia into distinct processes, which, in the course of a few hours, extend to a length of $10-15 \mu \mathrm{m}$. Once they attain this length, they exhibit little net elongation, although they remain motile and extend and retract for short distances. At the light-microscopic lcvel, all of the minor processes are similar in appcarance and growth characteristics.

It is not certain what relationship minor processes have to processes that occur in situ. Similar processes have been observed in light-microscopic studies of immature neuroblasts during, or shortly after, migration. Such processes have been described for cells in the hippocampal and cingulate cortices (Shoukimas and Hinds, 1978; Nowakowski and Rakic, 1979), as well as in other regions of the CNS (e.g., Moody and Heaton, 

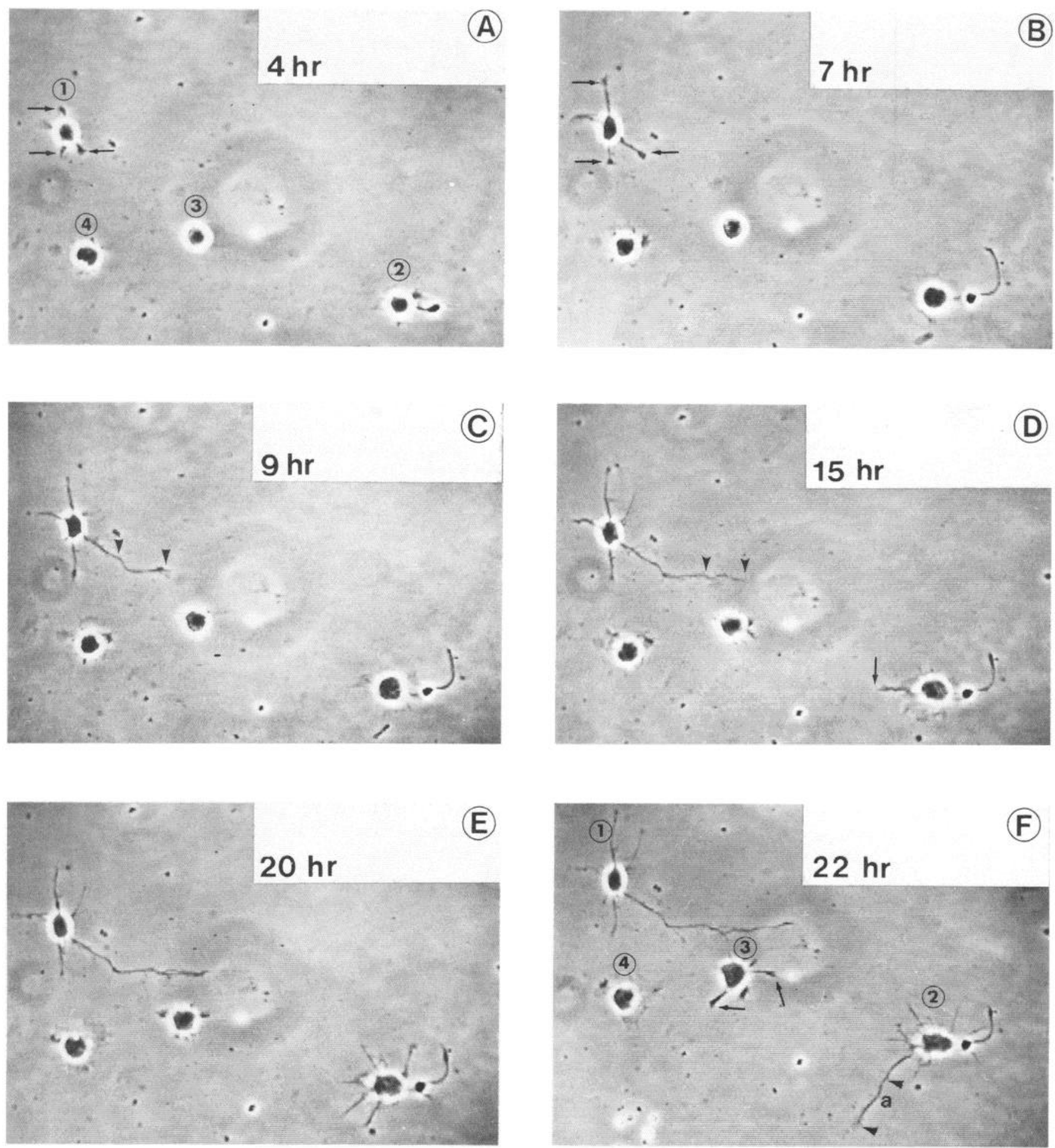

Figure 6. Individual frames from a time-lapse video recording showing the dynamics of axonal and dendritic outgrowth, elongation, and branching for 4 individual cells. The time after plating is shown on each micrograph. $A$, After $4 \mathrm{hr}$, only one cell (cell $l$ ) has begun to put out definitive processes (arrows). The other cells appear round, although at higher magnification lamellipodia would probably be visible (compare with Fig. 5). $B$. During the next $3 \mathrm{hr}$, all of the processes from cell 1 increased in length; this cell has reached the second phase of development, the stage of minor processes. None of the other cells developed processes, although lamellipodia became more clearly visible (cells 2 and 4 ). (The curving process visible to the right of cell 2 is actually the fragment of a process that was detached from a cell during dissociation; it is not an outgrowth from this cell.) $C$, In the interval of $2 \mathrm{hr}$ between this and the preceding micrograph, one of the processes of cell 1 elongated for a considerable distance (marked by the 2 arrowheads), becoming the axon. Its rate of elongation is shown in Figure $7 \mathrm{~A}$. The remaining minor processes underwent no net elongation during this interval, although they exhibited continuous motility (judged from the time-lapse recording). There was no change in the appearance of cells $2-4$. D, By $15 \mathrm{hr}$ after plating, the first process appeared from cell 2 (arrow). The axon of cell 1 elongated further, and an additional minor process appeared. $E$. In the interval between 15 and $20 \mathrm{hr}$ after plating, cell 2 developed several minor processes. Elongation of the axon from cell 1 ceased. Lamellipodia-like extensions appeared at points around the periphery of cell 3, but no definitive processes as yet formed. $F$, By $22 \mathrm{hr}$ after plating, one of the minor processes of cell 2 acquired axonal characteristics, extending $51 \mu \mathrm{m}$ in an interval of $2 \mathrm{hr}$ 

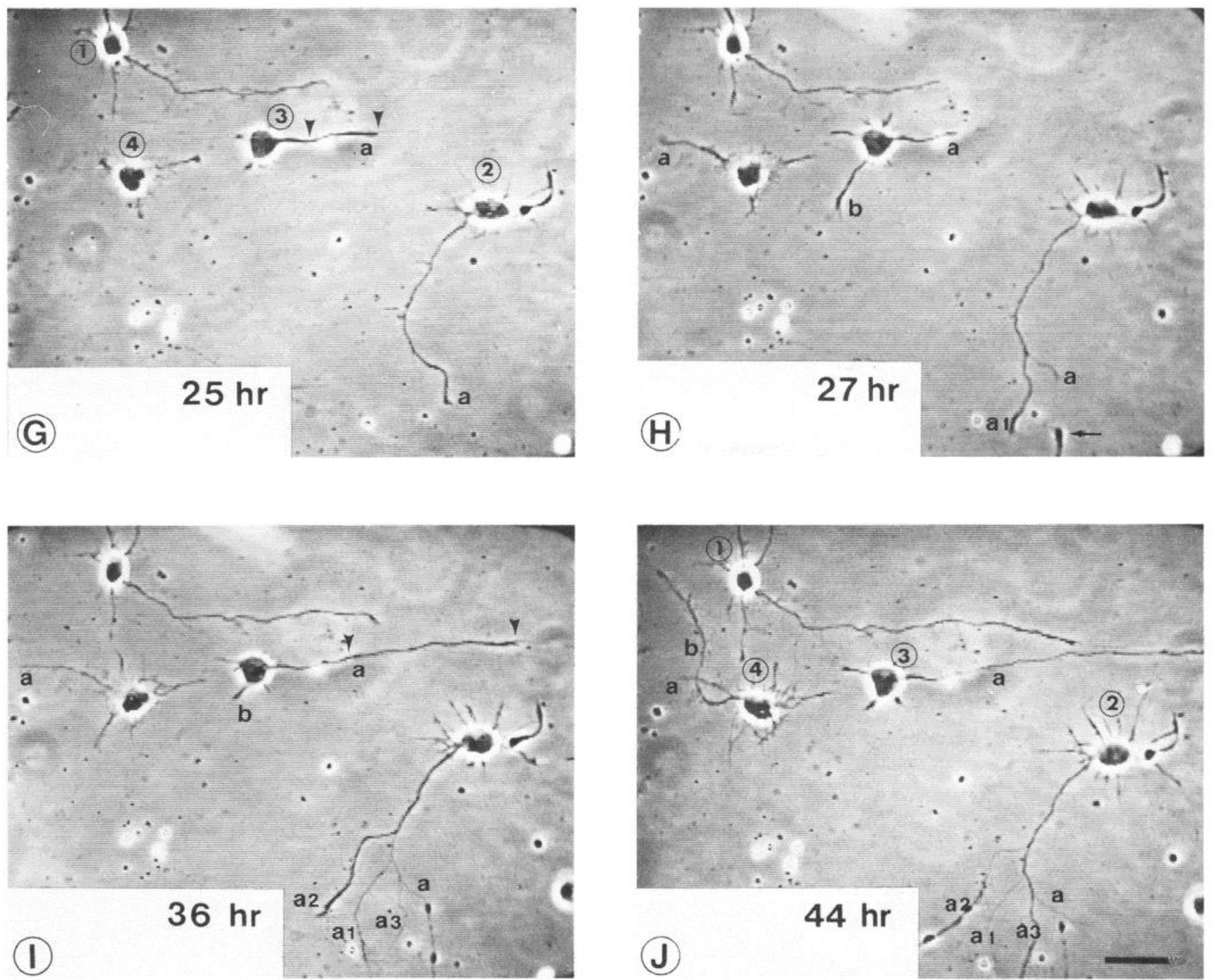

(distance marked by arrowheads). In the case of this cell, the axon was clearly not the first process to appear (compare $D$ and $F$ ). The axon of cell 1 resumed its elongation, and minor processes arose from cell 3 (arrows). $G-J$, Growth of these 4 cells during the second day in culture. During this period, the axon of cell $l$ nearly doubled in length, undergoing intervals of elongation (e.g., between 27 and $36 \mathrm{hr}$ ) with intervening lag periods (e.g., between 25 and $27 \mathrm{hr}$ ). The development of cell 2 during this period was marked by the appearance of several axonal branches, one between 25 and $27 \mathrm{hr}(a 1$ in $H), 2$ more between 27 and $35 \mathrm{hr}(a 2$ and $a 3$ in $I)$. All 3 branches arose as collaterals from the axonal shaft at a point proximal to the axonal growth cone. An axon from a neighboring cell entered this field from below (arrow in $H$ ) and contacted the axonal arbor of cell 2 between 27 and $36 \mathrm{hr}$ after plating. The axonal development of cells 3 and 4 was more complicated. In the interval between $22 \mathrm{and} 28 \mathrm{hr}$, one of the minor processes of cell $3(a)$ acquired axonal characteristics, elongating to a distance of about $60 \mu \mathrm{m}$ from the soma (arrowheads in $G$ ). During the subsequent $2 \mathrm{hr}$ this process stopped growing and a second minor process $(b$ in $H$ ) elongated at a rate characteristic of axons. Between 27 and $36 \mathrm{hr}(I)$ this second, axonlike process stopped elongating and retracted, while the first resumed its rapid elongation, attaining a length of $150 \mu \mathrm{m}$ by $48 \mathrm{hr}$ after plating $(J)$. Minor processes appeared from cell 4 after $25 \mathrm{hr}$ in vitro $(G)$; one of these acquired axonal characteristics $2 \mathrm{hr}$ later $(a$ in $H)$ and grew to a length of $50 \mu \mathrm{m}$ by $36 \mathrm{hr}(I)$. The cell's definitive axon $(b$ in $J)$ arose from a lamellipodium near the base of process $a 40 \mathrm{hr}$ after plating. By $44 \mathrm{hr}$ after plating, it had reached $73 \mu \mathrm{m}$ from the soma; process a had retracted to the length of a minor process. When this series of observations ended after $46 \mathrm{hr}$ in vitro, each of the 4 cells had a single axon and several minor processes. In the course of the development illustrated here, contacts occurred between minor processes from cell 1 and $4(I)$, and between minor processes from cell 3 and the axon of cell 1 (one at $23 \mathrm{hr}$, another at $29 \mathrm{hr}$ ). These contacts had withdrawn by the end of the observation period. Scale bar, $20 \mu \mathrm{m}$.

1981; Bicknell and Beal, 1984). In none of these cases is it known whether the definitive axon or the definitive dendrites arise from these short processes, as occurs in hippocampal cell cultures, or whether the short processes simply disappear.

Stage 3: formation and growth of the axon. Several hours after the appearance of minor processes, a rather abrupt change occurs: one of the minor processes begins to grow at a much more rapid rate. From this stage onward, its rate of growth will average
5-10 times greater than the other processes of the cell. This process is the axon, and it can be identified unequivocally as soon as its growth spurt begins. At this point, the cell has become polarized. All of the cells we observed by time-lapse recording followed this pattern of axon formation, but our sample was not large enough to detect exceptions, should they occur infrequently. For example, some cells in these cultures develop 2 axons (Bartlett and Banker, 1984a). 

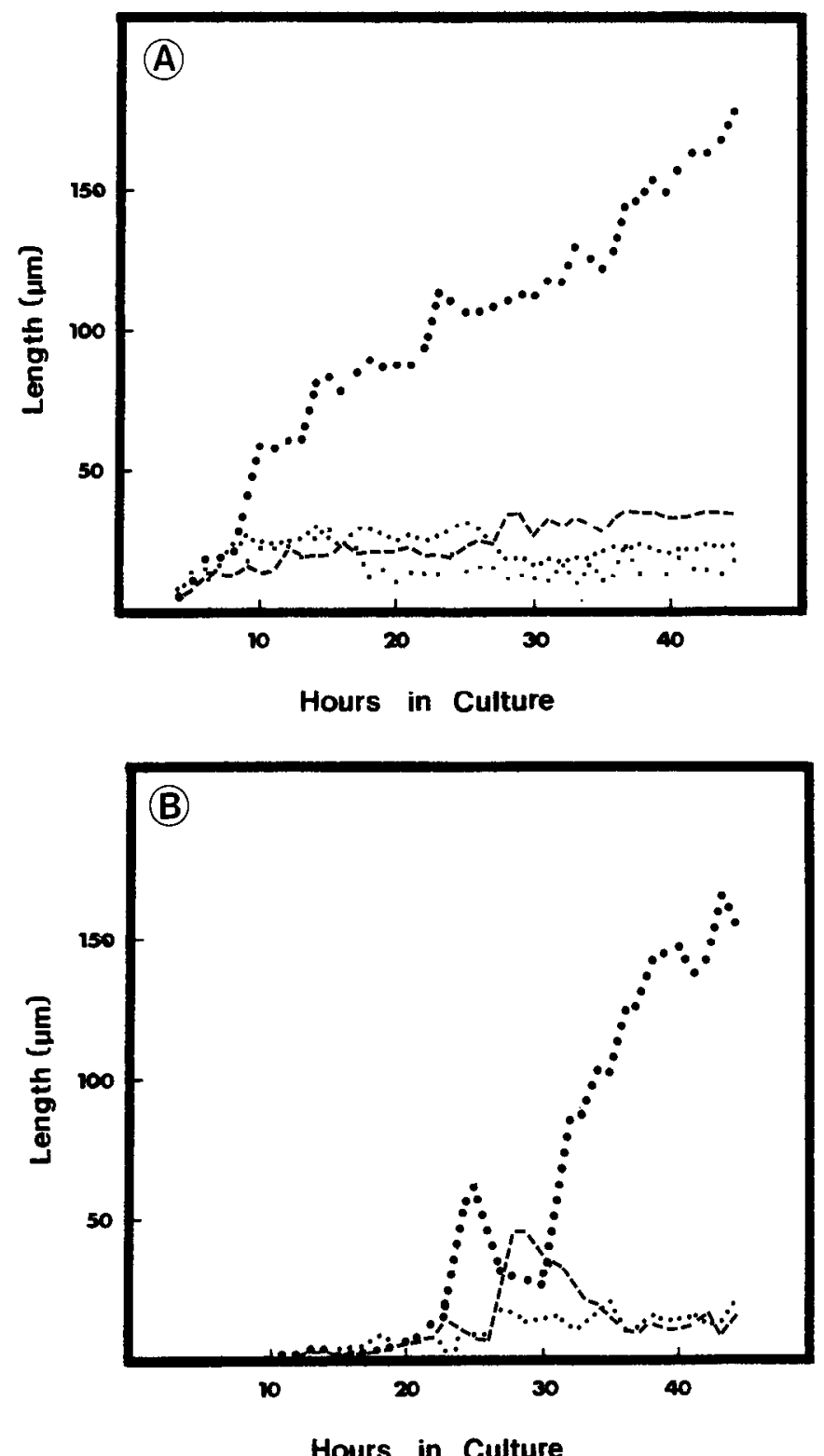

Figure 7. The rate of process elongation during the first $45 \mathrm{hr}$ in vitro. $A$, Length of each of the processes of cell 1 from Figure 6 , measured from the soma along the process to its tip. $B$, Comparable data for 3 of the processes of cell 3 in Figure 6 . In each case the definitive axon is represented by the large filled circles. For the cell in $A$, the outgrowth of minor processes was apparent by $6 \mathrm{hr}$. At $8 \mathrm{hr}$, one of these began to grow much more rapidly than the others. It underwent a series of active periods of elongation, punctuated by stationary periods, ultimately extending to about $175 \mu \mathrm{m}$ from the soma after $45 \mathrm{hr}$. The behavior of the 3 remaining, minor processes continued unchanged throughout this period, showing short extensions or retractions, but little net growth. The development of the cell in $B$ was rather different. The appearance of its minor processes and the establishment of its axon occurred considerably later. In addition, 2 different processes exhibited the rapid growth rate characteristic of axons. The first of these (corresponding to $a$ in Fig. $6 G$ ) began to grow rapidly about $24 \mathrm{hr}$ after plating (large filled circles). A few hours later, its growth stopped, another minor process (corresponding to $b$ in Fig. $6 H$ ) bcgan to grow rapidly (dashed line), and the first retracted somewhat. Subsequently the first process resumed its rapid growth and became the definitive axon, attaining a length of more than $150 \mu \mathrm{m}$. The second process retracted but did not disappear entirely; instead, in its later growth, it became indistinguishable from the cell's other minor processes (small filled circles).
How is it that one neuronal process, the axon, acquires properties distinct from the other processes arising from the same cell? One obvious possibility is that this is determined by the timing of process outgrowth: the first process to arise from the cell becomes the axon; any succeeding processes become dendrites. Our results show that this simple idea is not correct, at least for hippocampal neurons that develop in culture. Several minor processes all arise at about the same time, and the first of them does not necessarily become the axon (e.g., cell 2 in Fig. 6).

When do neuronal processes become specified as axons or dendrites? Are they determined at the time of their initiation, or do they acquire their definitive identity only at some later time? This question must finally be addressed by experimental methods, but our observations are consistent with the latter possibility. First, the initial processes that arise from the cell appear identical on the basis of their light-microscopic morphology and their patterns of motility. Second, and more suggestive, in a few cases the determination of the axon exhibited an apparent plasticity (e.g., cells 3 and 4, Fig. 6). First one process began to grow at a rate typical of axons, then its growth ceased and a different process took on axonal characteristics. In one case the second process became the definitive axon; in another, the first resumed its growth while the second retracted and became a dendrite. These observations raise the possibility that several, perhaps all, of the initial processes are capable of becoming axons, but when one acquires axonal properties the remaining processes are prevented from becoming axons.

Stage 4: growth of dendrites. Like the axon, dendrites develop from the minor processes that appear during the first day in culture, but signifient dendritic growth begins only after about $4 \mathrm{~d}$ in culture, 2-3 d after axonal outgrowth. The temporal difference in the initiation of significant axonal versus dendritic outgrowth parallels that frequently observed in situ: in many instances, including that of developing hippocampal neurons, axons arise before dendrites (Nowakowski and Rakic, 1979).

Dendritic growth differs from axonal growth in 2 other obvious but important respects. First, dendrites grow more slowly than axons. This seems intuitively obvious from the great difference in length of mature axons and dendrites, but we believe our observations are the first to determine and compare the rates of axonal and dendritic outgrowth of individual cells. These rates, averaged over an interval of $24 \mathrm{hr}$, differ by at least a factor of 5. Such differences in growth rate are apparently endogenous, since, under the circumstances of our observations, the developing dendrites are not contacted by afferents and the developing axons do not innervate their target cells. Of coursc, these rates might well be modulated when such cellular interactions occur. Second, unlike axons, several dendrites grow at the same time. If some internal mechanism prevents simultaneous elongation of more than one process during the phase of axon initiation, it must be altered when dendritic development begins.

\section{Comparison with previous studies of neurite growth in culture}

Previous observations of neurite development by living nerve cells have focused almost entirely on cells from the PNS. The outgrowth of axons by hippocampal neurons in culture is similar in many respects, but there are several important differences.

First, there appears to be a difference in how axon number is determined. In mature cultures, sympathetic neurons typically have a single axon and several dendrites (Wakshull et al., 1979; 

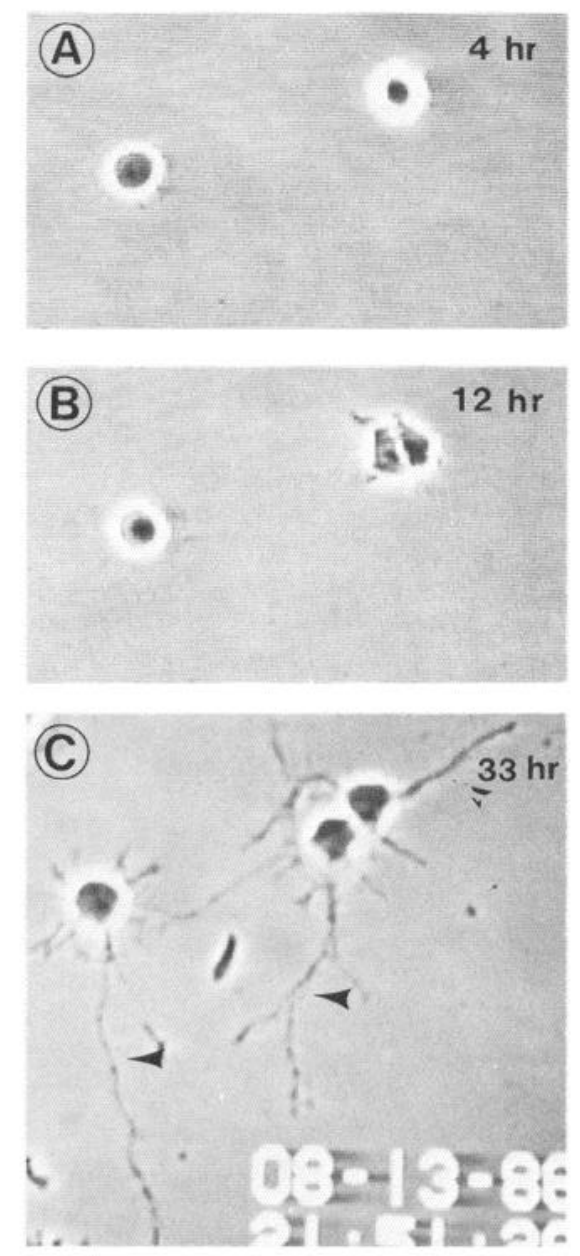
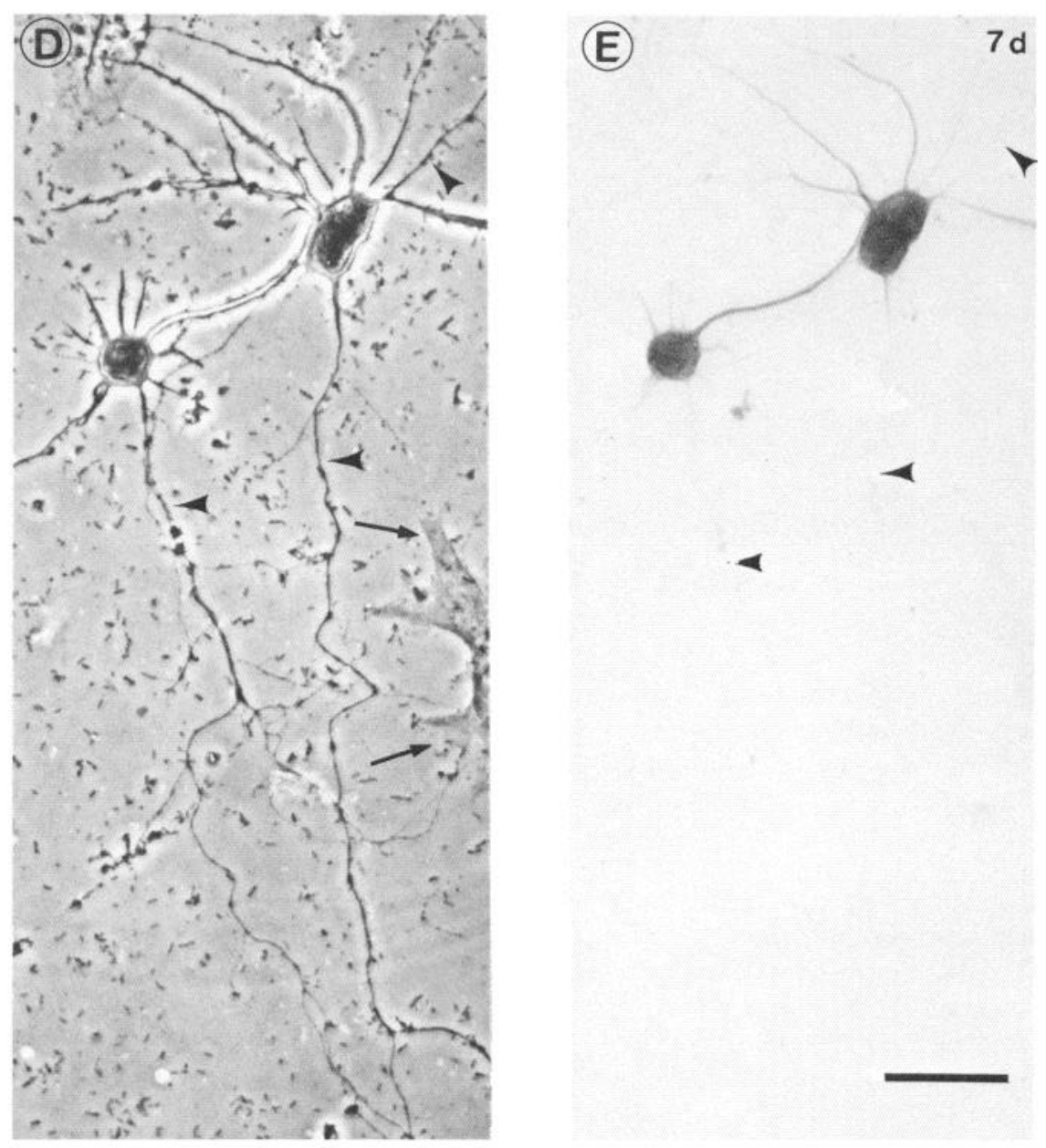

Figure 8. The establishment of axons and dendrites following cell division in culture. The series of photomicrographs, taken from a time-lapse record, illustrates development after $4 \mathrm{hr}(A), 12 \mathrm{hr}(B)$, and $33 \mathrm{hr}(C)$ in vitro. The cell at right in $A$ underwent division after $10 \mathrm{hr}$ in vitro. Both daughter cells first developed minor processes and then a single axon (arrowheads in $C$ ), just like cells that develop from postmitotic neuroblasts, such as the cell at left. Six days later, the culture was fixed and immunostained to localize MAP2, as illustrated in the phase-contrast and brightfield photomicrographs ( $D$ and $E$, respectively). Both of the daughters of the cell that divided expressed the neuron-specific protein MAP2; the non-neuronal cell present in this field did not (arrows). Moreover, the MAP2 present in these 2 neurons was restricted to the somatodendritic domain, just like cells that undergo their final division in situ. Scale bar, $25 \mu \mathrm{m}$.

Furshpan et al., 1986; Peng et al., 1986; Higgins et al., 1988). Initially, sympathetic and other peripheral neurons put out several, apparently identical, processes (Bray, 1973; Letourneau, 1975a; Role and Fischbach, 1987) that tend to resemble axons in their light- and electron-microscopic morphology (Yamada et al., 1971; Bunge, 1973), their rate of elongation (Bray, 1973; Letourneau, 1975a), and their ability to form presynaptic terminals (Role et al., 1987). Thus, it may be that some classes of peripheral neurons establish their mature form through the retraction of supernumerary axonlike processes during the course of their development in culture; this has been observed directly for ciliary neurons (Role and Fischbach, 1987). This stands in marked contrast to the morphogenesis of hippocampal neurons in culture, which in most instances put out only a single axon from the outset of their development.

Second, the average growth rate of hippocampal axons $(5 \mu \mathrm{m} /$ $\mathrm{hr}$ during the first $18 \mathrm{hr}$ of axonal elongation) is about an order of magnitude slower than the rates typical of PNS neurites (40$100 \mu \mathrm{m} / \mathrm{hr}$; see Bray, 1973; Luduena, 1973a, b; Letourneau, 1975a). Rogers et al. (1983) have also noted that the average length of retinal neurites, measured after $2 \mathrm{~d}$ in culture, is much shorter than the length of peripheral ganglion cell neurites grown under identical conditions. In the case of hippocampal neurons, the most important reason for the slow rate of increase in axonal length is that growth is intermittent. Axons are stationary for a greater proportion of the time than they are actively growing. The maximal rate of axonal elongation we observed, measured over intervals of 1-2 hr was much more comparable to the rates of elongation reported for PNS cells. The significance of the remaining, roughly 2 -fold, difference in rates of growth during periods of active elongation is unclear. There could be important endogenous differences between CNS and PNS cells. Alternatively, optimal substrates for CNS growth in culture may yet await discovery.

A third difference between our observations and those of previous investigators concerns the mode of axonal branching. In Bray's (1973) classic studies of sympathetic neurons, branching occurred by bifurcation of the growing tip, each branch capturing a portion of the original growth cone; collateral branching was not observed. In contrast, our observations of hippocampal neurons suggest that branching occurs predominantly by the formation of collaterals along the axon some time after the initial 

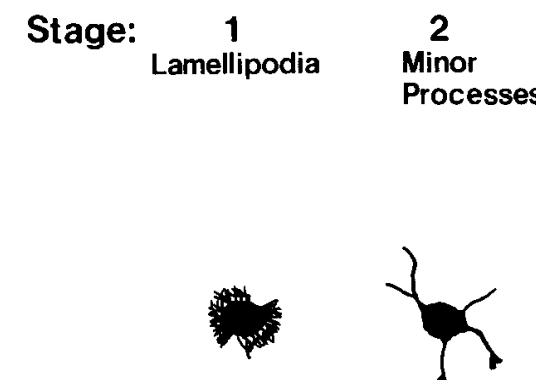
Days in
Culture:

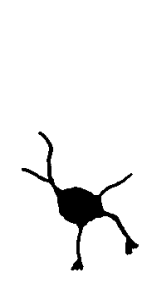

0.5
3

Axonal
Outgrowth

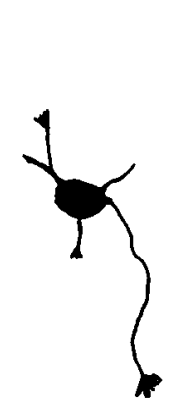

1.5
4

Dendritic

Outgrowth

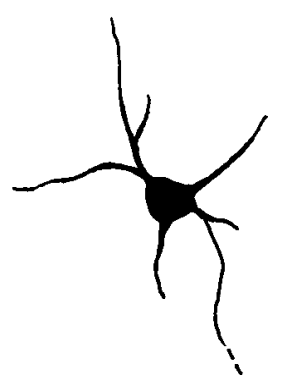

4

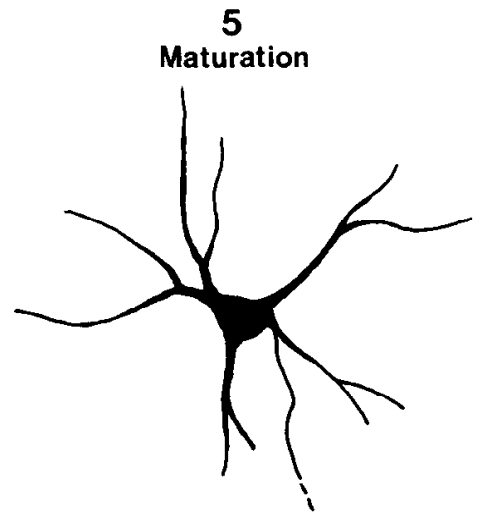

$>7$

Figure 9. Stages of development of hippocampal neurons in culture. The approximate times at which cells enter each of the stages is indicated.

growth cone has passed this point. This result is not unprecedented. For example, Speidel $(1941,1942)$ described examples of the extension and retraction of collateral branches of axons in tadpole skin. Indeed, sensory neurites, which normally branch at their tips in culture, can be induced by amputation to form growth cones and even collateral branches at any point along their lengths (Bray et al., 1978). We do not regard these differing observations as contradictory; rather, they suggest that axons are capable of forming branches by both of these modes. Specific environmental conditions, such as the character of the substrate or the presence of trophic agents like NGF, may modulate the frequency with which each mode of branching occurs. On the other hand, it is premature to generalize Bray's observations to quite different situations, such as the induction of dendritic branching in situ (Vaughn and Henrikson, 1974; Berry, 1982).

\section{The role of microtubules in process outgrowth and the establishment of polarity}

The role of microtubules in the extension of neuronal processes has been extensively studied at the morphological and biochemical levels (Yamada et al., 1970; Drubin et al., 1985; Black et al., 1986). The reorganization that occurs as lamellipodia become growth cones and microtubules assemble and become aligned in newly forming processes is likely the same in hippocampal neurons as in the more frequently studied peripheral neurons and PC12 cells. However, subsequent events in the morphogenesis of hippocampal neurons suggest that the control microtubule assembly within a single cell can be considerably more complex than studies of peripheral neurons would suggest. The establishment of the axon (i.e., the transition from stage 2 to stage 3) must involve a refined spatial control of microtubule assembly to permit the selective extension of one process while the other processes remain stationary. Since axonal elongation is intermittent, microtubule assembly in the axon must be under temporal control as well. Moreover, the formation of collateral branches must be accompanied by a redirection of the transport of microtubules within the axon. The growth of dendrites is marked by still further changes in the control of microtubule assembly. Net assembly of microtubules, confined predominantly to the axon during stage 3, must now occur in all of the cell's processes. However, since the growth rate of the axon is much greater than that of the dendrites, the rate of microtubule assembly must be controlled separately for the 2 sets of pro- cesses. All of these events point to the importance of elucidating the changes that occur in the control of microtubule organization and function during neuronal morphogenesis.

Because they are differentially distributed, microtubule-associated proteins (MAPs) might be considered prime candidates to regulate the spatial control of microtubule function during neuronal development. In the processes of mature neurons, one neuronal MAP, MAP2, is preferentially localized in dendrites, whereas another, $t a u$, is preferentially localized in axons. At the time hippocampal neurons become polarized, however, MAP2 and tau are not differentially distributed; both are present in the axon and in the minor processes (Caceres et al., 1986; Dotti et al., 1987).

Kirschner and Mitchison (1986) have recently proposed that cells acquire an asymmetric shape and become polarized by the selective stabilization of a subset of their microtubules. The microtubules of nonpolarized cells in culture are dynamically unstable (Soltys and Borisy, 1985; Schulze and Kirschner, 1986). According to Kirschner and Mitchison's (1986) hypothesis, an external signal impinging on one region of a cell causes a local biochemical change that preferentially increases the stability of microtubules extending into that region. The enhanced microtubule stability leads to elongation of the cell-or, in the case of a neuron, to extension of a process -in the direction of the signal. This model, applied to the specific case of hippocampal neurons developing in culture, predicts that the transition from stage 2 to stage 3 would be marked by the selective stabilization of microtubules in the elongating axon. This aspect of the model is quite plausible and directly testable.

In a more general sense, however, Kirschner and Mitchison's (1986) suggestion that polarization arises in response to an external signal is not compatible with our data. In situ signals might operate to determine the orientation of axonal outgrowth, but our results show that polarization per se occurs in the apparent absence of external signals. To understand how a neuron establishes its characteristic shape, with a single axon and several dendrites, one must look to the internal organization of the cell itself.

Note added in proof: Recent experiments (Dotti and Banker, 1987) show that if the axons of hippocampal neurons are cut during stage 3 of development, one of the minor processes frequently becomes the new axon. The stump of the initial axon often remains and becomes a dendrite. 


\section{References}

Bamburg, J. R., D. Bray, and K. Chapman (1986) Assembly of microtubules at the tip of growing axons. Nature 321: 788-790.

Banker, G. (1980) Trophic interactions between astroglial cells and hippocampal neurons in culture. Science 209: 809-810.

Banker, G., and W. Cowan (1977) Rat hippocampal neurons in dispersed cell culture. Brain Res. 126: 397-425.

Banker, G., and W. Cowan (1979) Further observations on hippocampal neurons in dispersed cell cultures. J. Comp. Neurol 187: 469494.

Banker, G., and J. Mazurkiewicz (1982) Autoradiographic studies of alpha-bungarotoxin binding in hippocampal cell cultures. Soc. Neurosci. Abstr. 8: 851 .

Banker, G., and A. Waxman (1988) Hippocampal neurons generate natural shapes in cell culture. In Intrinsic Determinants of Neuronal Form, R. Lasek and M. B. Black, eds., Liss, New York (in press).

Bartlett, W., and G. Banker (1984a) An electron microscopic study of the development of axons and dendrites by hippocampal neurons in culture. I. Cells which develop without intercellular contacts. J. Neurosci. 4: 1944-1953

Bartlett, W., and G. Banker (1984b) An electron microscopic study of the development of axons and dendrites by hippocampal neurons in cultures. II. Synaptic relationships. J. Neurosci. 4: 1934-1965.

Berry, M. (1982) Cellular differentiation: development of dendritic arborizations under normal and experimentally altered conditions. Neurosci. Res. Prog. Bull. 20: 451-461.

Bicknell, H., and J. Beal (1984) Axonal and dendritic development of substantia gelatinosa neurons in the lumbosacral spinal cord of the cat. J. Comp. Neurol. 226: 508-522.

Black, M., J. Aletta, and L. Greene (1986) Regulation of microtubule composition and stability during nerve growth factor-promoted neurite outgrowth. J. Cell Biol. 103: 545-557.

Booher, J., and M. Sensenbrenner (1972) Growth and cultivation of dissociated neurons and glial cells from embryonic chick, rat, and human brain in flask cultures. Neurobiol. 2: 97-105.

Bottenstein, J. E., and G. H. Sato (1979) Growth of a rat neuroblastoma cell line in serum-free supplemented medium. Proc. Natl. Acad. Sci. USA 76: 514-519.

Bray, D. (1970) Surface movement during the growth of single explanted neurons. Proc. Natl. Acad. Sci. USA 65: 905-910.

Bray, D. (1973) Branching patterns of isolated sympathetic neurons. J. Cell Biol. 56: 702-712.

Bray, D., and K. Chapman (1985) Analysis of microspike movements on the neuronal growth cone. J. Neurosci. 5: 3209-3213.

Bray, D., C. Thomas, and G. Shaw (1978) Growth cone formation in cultures of sensory neurons. Proc. Natl. Acad. Sci. USA 75: 52265229.

Bunge, M. (1973) Fine structure of nerve fibers and growth cones of isolated sympathetic neurons in cultures. J. Cell. Biol. 56: 713-735.

Caceres, A., G. Banker, O. Steward, L. Binder, and M. Payne (1984) MAP2 is localized to the dendrites of hippocampal neurons which develop in culture. Dev. Brain Res. 13: 314-318.

Caceres, A., G. Banker, and L. Binder (1986) Immunocytochemical localization of tubulin and microtubule-associated protein 2 during the development of hippocampal neurons in culture. J. Neurosci. 6: 714-722.

Collins, F. (1978) Axon initiation by ciliary neurons in culture. Dev. Biol. 65: 50-57.

Davis, L., G. Banker, and O. Steward (1987) Selective dendritic transport of RNA in hippocampal neurons in culture. Nature 330: 477479.

Dotti, C. G., and G. A. Banker (1987) Experimentally induced alteration in the polarity of developing neurons. Nature 330:254-256.

Dotti, C. G., G. Banker, and L. I. Binder (1987) The expression and distribution of the microtubule-associated proteins tau and microtubule associated protein 2 in hippocampal neurons in the rat in situ and in cell culture. Neuroscience (in press)

Drubin, D., S. Feinstein, E. Shooter, and M. Kirschner (1985) Nerve growth factor-induced neurite outgrowth in PC 12 cells involves the coordinate induction of microtubule assembly and assembly-promoting factors. J. Cell Biol. 101: 1799-1807.

Eisen, J., P. Myers, and M. Westerfield (1986) Pathway selection by growth cones of identified motoneurons in live zebra fish embryos. Nature 320: 269-271.

Furshpan, E. J., S. C. Landis, S. G. Matsumoto, and D. D. Potter (1986)
Synaptic functions in rat sympathetic neurons in microcultures. I. Secretion of norepinephrine and acetylcholine. J. Neurosci. 6: 10611079.

Gundersen, R., and J. N. Barrett (1980) Characterization of the turning response of dorsal root neurites towards nerve growth factor. J. Cell Biol. 87: 546-554.

Harris, A. (1973) Location of cellular adhesions to solid substrata. Dev. Biol. 35: 97-114.

Higgins, D., A. Waxman, and G. Banker (1987) The distribution of Microtubule-associated protein 2 changes when dendritic growth is induced in rat sympathetic neurons in vitro. Neuroscience (in press).

Kirschner, M., and T. Mitchison (1986) Beyond self-assembly: From microtubules to morphogenesis. Cell 45: 329-342.

Landis, S. C. (1983) Neuronal growth cones. Annu. Rev. Physiol. 45: 567-580.

Letourneau, P. (1975a) Possible roles for cell-to-substratum adhesion in neuronal morphogenesis. Dev. Biol. 44: 77-91.

Letourneau, P. (1975b) Cell-to-substratum adhesion and guidance of axonal elongation. Dev. Biol. 44: 92-101.

Lindsley, T., P. De Camilli, and G. Banker (1987) The influence of cell-cell contact on the distribution of synapsin $I$ in hippocampal neurons in culture. Soc. Neurosci. Abstr. 13:318.

Luduena, M. A. (1973a) The growth of spinal ganglion neurons in serum-free medium. Dev. Biol. 33: 470-476.

Luduena, M. A. (1973b) Nerve cell differentiation in vitro. Dev. Biol. 33: 268-284.

Matus, A., R. Bernhardt, R. Bodmer, and D. Alaimo (1986) Microtubule-associated protein 2 and tubulin are differently distributed in the dendrites of developing neurons. Neuroscience 17: 371-389.

Moody, S., and M. Heaton (1981) Morphology of migrating trigeminal motor neuroblasts as revealed by horseradish peroxodase retrograde labeling techniques. Neuroscience 6: 1707-1723.

Nowakowski, R., and P. Rakic (1979) The mode of migration of neurons to the hippocampus: A Golgi and electron microscopic analysis in foetal rhesus monkey. J. Neurocytol. 8: 697-718.

Patel, N., and M.-M. Poo (1984) Perturbation of the direction of neurite growth by pulsed and focal electric fields. J. Neurosci. 4:29392947.

Peng, I., L. I. Binder, and M. Black (1986) Biochemical and immunological analyses of cytoskeletal domains of neurons. J. Cell Biol. 102: 252-262.

Purves, D., R. D. Hadley, and J. T. Voyvodic (1986) Dynamic changes in the dendritic geometry of individual neurons visualized over periods of up to three months in the superior cervical ganglion of living mice. J. Neurosci. 6: 1051-1060.

Revel, J., P. Hoch, and D. Ho (1974) Adhesion of culture cells to their substratum. Exp. Cell Res. 84: 207-218.

Rogers, S., P. Letourneau, S. Palm, J. McCarthy, and L. Furcht (1983) Neurite extension by peripheral and central nervous system neurons in response to substrate-bound fibronectin and laminin. Dev. Biol. 98: 212-220.

Role, L. W., and G. D. Fischbach (1987) Changes in the number of chick ciliary ganglion neuron processes with time in cell culture. $J$. Cell Biol. 104: 363-370.

Role, L. W., D. G. Roufa, and G. D. Fischbach (1987) The distribution of acetylcholine receptor clusters and sites of transmitter release along chick ciliary ganglion neurite-myotube contacts in culture. J. Cell Biol. 104: 371-379.

Rothman, S., and W. M. Cowan (1981) A scanning electron microscope study of the in vitro development of dissociated hippocampal cells. J. Comp. Neurol. 195: 141-155.

Schlessinger, A. R., W. M. Cowan, and L. W. Swanson (1978) The time of origin of neurons in Ammon's horn and the associated retrohippocampal fields. Anat. Embryol. 154: 153-173.

Schulze, E., and M. Kirschner (1986) Microtubule dynamics in interphase cells. J. Cell Biol. 102: 1020-1031.

Shaw, G., G. Banker, and K. Weber (1985) An immunofluorescence study of neurofilament expression by developing hippocampal neurons in tissue culture. Eur. J. Cell Biol. 39: 205-216.

Shoukimas, G., and J. Hinds (1978) The development of the cerebral cortex in the embryonic mouse: An electron microscopic serial section analysis. J. Comp. Neurol. 179: 795-830.

Soltys, B. J., and G. G. Borisy (1985) Polymerization of tubulin in vivo: Direct evidence for assembly onto microtubule ends and from centrosomes. J. Cell Biol. 100: 1682-1689.

Speidel, C. (1941) Adjustments of nerve endings. Harvey Lect. 36: 126-158. 
Speidel, C. (1942) Studies of living nerves. VII. Growth adjustments of cutaneous terminal arborizations. J. Comp. Neurol. 76: 57-73.

Trinkaus, J. P. (1973) Surface activity and locomotion of Fundulus deep cells during blastula and gastrula stages. Dev. Biol. 30: 69-103.

Vaughn, J. E., and C. K. Henrikson (1974) A quantitative study of synapses on motor neuron dendritic growth cones in developing mouse spinal cord. J. Cell Biol. 60: 664-672.

Wakshull, E., M. I. Johnson, and H. Burton (1979) Postnatal rat sympathetic neurons in culture. I. A comparison with embryonic neurons. J. Neurophys. 4: 1410-1425.
Wessells, N., S. Johnson, and R. Nuttall (1978) Axon initiation and growth cone regeneration in cultured motor ncurons. Exp. Cell Res. 117: 335-345.

Yamada, K., B. Spooner, and N. Wessells (1970) Axon growth: Roles of microfilaments and microtubules. Proc. Natl. Acad. Sci. USA 66: 1206-1212.

Yamada, K., B. Spooner, and N. Wessells (1971) Ultrastructure and function of growth cones and axons in cultured nerve cells. J. Cell Biol. 49: 614-635. 